\title{
The Effect of WebQuest on Writing Ability: A Case Study of EFL in Indonesia
}

\author{
Sri Wahyuni ${ }^{1}$, Fauzul Etfita ${ }^{2}$, Siska Handayani 3 \\ DOI: $10.35445 /$ alishlah.v13i1. 446
}

\begin{tabular}{l}
\hline Article Info \\
\hline Keywords: \\
Ability \\
Procedure Text \\
WebQuest \\
Writing
\end{tabular}

Kata kunci:

Kemampuan

Teks Prosedur

WebQuest

Menulis

\begin{abstract}
This research aimed to find out students' writing at vocational school YPPI Tualang and know how WebQuest improves students' writing procedure text of second-year students at vocational school YPPI Tualang. This current study was experimental research which was held at the vocational school YPPI Tualang. The experimental research involved two groups of students; they were the experimental group and the control group. The research subjects were the second-year students of vocational school YPPI Tualang. The sample of this research was taken randomly. The experimental group that belongs to the experimental group included 20 students, while the students of the control group belong to the control group were 20 students. The researcher's findings included the research results: the experimental class's analysis results show that the mean score of pre-tests in the experimental class was 63.9. The mean score of the post-test was 77.4. Meanwhile, the control class's analysis result shows that the mean score of pre-tests in the control class was 53.8, and the mean score of the post-test was 58.4. It shows that the experimental class experiences improvement in their writing test. The hypothesis testing indicates that the experimental class students' score was higher than the control class. It can be concluded that WebQuest was effective for enhancing learning writing and providing a positive learning experience.
\end{abstract}

\begin{abstract}
Abstrak
Penelitian ini bertujuan untuk mengetahui kemampuan menulis siswa di SMK YPPI Tualang dan untuk mengetahui bagaimana WebQuest meningkatkan kemampuan siswa tahun kedua di SMK YPPI Tualang meulis teks prosedur. Penelitian ini merupakan penelitian eksperimental yang dilaksanakan di SMK YPPI Tualang. Penelitian eksperimental melibatkan dua kelompok siswa yaitu kelompok eksperimen dan kelompok kontrol. Subjek penelitian adalah siswa tahun kedua SMK YPPI Tualang. Sampel penelitian ini diambil secara acak. Kelompok eksperimen yang termasuk dalam kelompok eksperimen berjumlah 20 siswa, sedangkan kelompok kontrol yang termasuk dalam kelompok kontrol berjumlah 20 siswa. Temuan peneliti meliputi hasil penelitian sebagai berikut: Hasil analisis kelas eksperimen menunjukkan bahwa rata-rata skor pre-tes kelas eksperimen adalah 63,9. Skor rata-rata post-tes adalah 77,4. Sementara itu, hasil analisis kelas kontrol menunjukkan bahwa nilai rata-rata pre-tes di kelas kontrol adalah 53,8 , dan rata-rata nilai post-tes adalah 58,4 . Hal tersebut menunjukkan bahwa kelas eksperimen mengalami peningkatan dalam tes menulisnya. Pengujian hipotesis menunjukkan bahwa nilai siswa kelas eksperimen lebih tinggi daripada kelas kontrol. Dapat disimpulkan bahwa WebQuest efektif untuk meningkatkan pembelajaran menulis dan memberikan pengalaman belajar yang positif.
\end{abstract}

\footnotetext{
${ }^{1}$ Universitas Islam Riau, Pekanbaru, Indonesia

Email: wahyunis@edu.uir.ac.id

2 Universitas Islam Riau, Pekanbaru, Indonesia

Email: fauzuletfita@edu.uir.ac.id

3 Universitas Islam Riau, Pekanbaru, Indonesia

Email: siskahandayani@student.uir.ac.id
}

Vol.13 (1) June, 2021

Received: March 17, 2021; Received in revised form: May 5, 2021; Accepted: May 10, 2021; Available online: June 5, 2021

This is an open access article under a Creative Commons Attribution-NonCommercial-ShareAlike 4.0 International License 


\section{INTRODUCTION}

Writing is one of the four language skills that have to be mastered by the students in learning English, and writing is one of the subjects considered problematic by the students (Wahyuni, 2017). It is often regarded as complicated learning because it is required some media. Writing should be practice, and the students also need time and particular tasks to improve their ability. Wahyuni (2015) stated that writing is a productive skill and natural activity taught in a structured way. On the other hand, writing ability is critical to be acquired by the students.

From the experience of Practice Teaching vocational school YPPI Tualang, the researcher found some writing problems. Most of the students had difficulty writing, such as when students made a short paragraph, they did not know how to build grammatically correct sentences. Some students felt confused ways got an idea, and lack of vocabulary made students unhappy and difficult to made short paragraphs. The researcher thought it was necessary to find the solution to the teaching and learning process problems. Therefore, the student's writing ability should be improved.

The relation to the problem, the researcher believed using WebQuest in teaching writing was one of the solutions (Lipscomb, 2003). WebQuest helps students through websites and focuses on the use of information rather than looking for information, and can build academic literacy by engaging students to conclude that it is not only reported but explored (Zheng et al., 2005). Parts of WebQuest can generally be displayed in Introduction (background), Task (task), Process (steps in doing the assignment), Evaluation (evaluation by the teacher for students after doing a task), and conclusion (Dodge, 1997). An additional part of this WebQuest is a Teacher Page that can provide input to other teachers through fresh and creative suggestions or ideas that can be used to create WebQuest (Pinantoan, 2013).

One of the teaching media that can help students is WebQuest (Şahin \& Baturay, 2016). Teaching through WebQuest, the learning process becomes interesting that given by the teacher. The teacher should create creative activities and make an enjoyable classroom situation to help studentsgeneralize their ideas and automatically improve their writing ability. The WebQuest guides the students to write systematically (Akhand, 2015).

The researcher intends to give new technological learning by using media. It is called "WebQuest". As one of the teaching media developed by Bernie Dodge from San Diego State University, WebQuest has been trying to make good use of the internet in the teaching-learning process (Strickland \& Nazzal, 2005). It became a media of teaching that can help students improve learning performance. That is why WebQuest can help teachers make their creativity in teachinglearning (Barros \& Carvalho, 2007).

These days, computers, smartphones, and other gadgets can connect to the internet and be an alternative learning tool (Sung et al., 2016). However, resources on the internet should be carefully selected by teachers to include a different perspective on the topic that is investigated. The material must follow the curriculum and syllabus mandated in school (Ghavifekr \& Rosdy, 2015).

Webquest is a computer application specially designed for use inside learning. Using WebQuest in writing means that teachers give the students more learning opportunities(Chuo, 2007; $\mathrm{Wu}, 2016)$. They can write some texts and discuss ideas on exciting issues. The first activities that students can do to improve writing skills are finding some difficult words and the main ideas of each paragraph. It is convinced that those activities will slowly upgrade their writing (Hadriana, 2017). Also, it could be a different idea in teaching writing because the majority believes that teaching writing should be in conventional method to obtain a good achievement (Raja \& Khan, 2018).

In contrast with the previous statement, WebQuest can be a medium to teach writing by integrating technology (Irzawati \& Asiah, 2013). Thus, this current study aimed to fill a gap in teaching writing by utilizing WebQuest. So, this recent study aimed to determine the effect of WebQuest on the writing ability of procedure text. 


\section{METHODS}

The current study design was experimental research, focus on a quantitative approach. The experiment was a test idea to figure out whether it affects an outcome of the dependent variable (Creswell, 2013). There were two variables: independent variable (variable $\mathrm{X}$ ) and dependent variable (variable Y). In this case, WebQuest was using an independent variable to know whether it influences the dependent variable or not. The dependent variable of this research was students writing ability. The design from this research was used in experiment class. The experiment class was given treatments through WebQuest. This research was conducted within six meetings. The researchers employed two variables in this research. WebQuest was the independent variable, and writing ability was the dependent variable.

The research was done in July 2019, and the location of this research at the vocational school YPPI Tualang Jl. Sepuluh KPR 1. The population of this research was the second-year students of vocational school YPPI Tualang. There were classes of the second year of vocational school YPPI Tualang consist of 100 students in XI classes.

The type of data in this study was quantitative data. The data was collected by checking the attendance of students. Then, a pre-test was given to students as a test before giving some treatment. This pre-test analyzed students' prior knowledge about writing skills. Next phase, treatments were given to them by asking them to read and learn procedure text through WebQuest. In WebQuest, there were some texts which contained procedure text and some questions that students must answer. It was used to develop their writing skill. Last, a post-test was given to students to determine any significant progress from students after doing treatment. The result of pre-test and post-test were compared statistically. It aimed to reveal the effect of WebQuest toward writing ability on procedure text of second-year students of vocational school YPPI Tualang.

In analysis data, the researchers employed a score of pre-test and post-test of the students. The scores were analyzed by utilizing statistical tests, variance, and homogeneity. The homogeneity test was applied to investigate whether the two classes were a homogenous variance or not. After teaching writing use WebQuest, the data were analyzed by statistical analysis version 24 .

\section{FINDINGS AND DISCUSSION}

\section{Pre-Test}

The pre-test was carried out to determine the students' early background capability who were selected as the sample. It was held to determine whether the experimental and control groups at the same level before applying a new strategy for the experimental group and the material was the test. In the first meeting, the teacher gave some topics (3 topics) to students, and students choose one issue that he wants to write down. After students doing the pre-test, the teacher explained about procedure text. This meeting's objective was to give the students a clear understanding of a procedure text by providing examples of a procedure text.

\section{a. Data Presentation of Pre-Test in Control Class}

The first analysis was the students' pre-test score in the control group, which shows students' ability in writing procedure text. The researcher presented the students' writing on the pre-test, the result as follows; the highest average score was 62, and the lowest average score was 44 . Moreover, in the control class, the total score that 20 students were 1.076, and the average score was 53.8 points (see figure 1).

\section{b. Data Presentation of Pre-Test in Experimental Class}

The students' results in writing skill, particularly in writing procedure text in the pre-test of experiment class, as follows; the highest average score was 68, and the lowest average score was 48 . Moreover, in experiment class, the total score that 20 students were 1.278, and the average score was 63.9 points (see figure 1 ). 


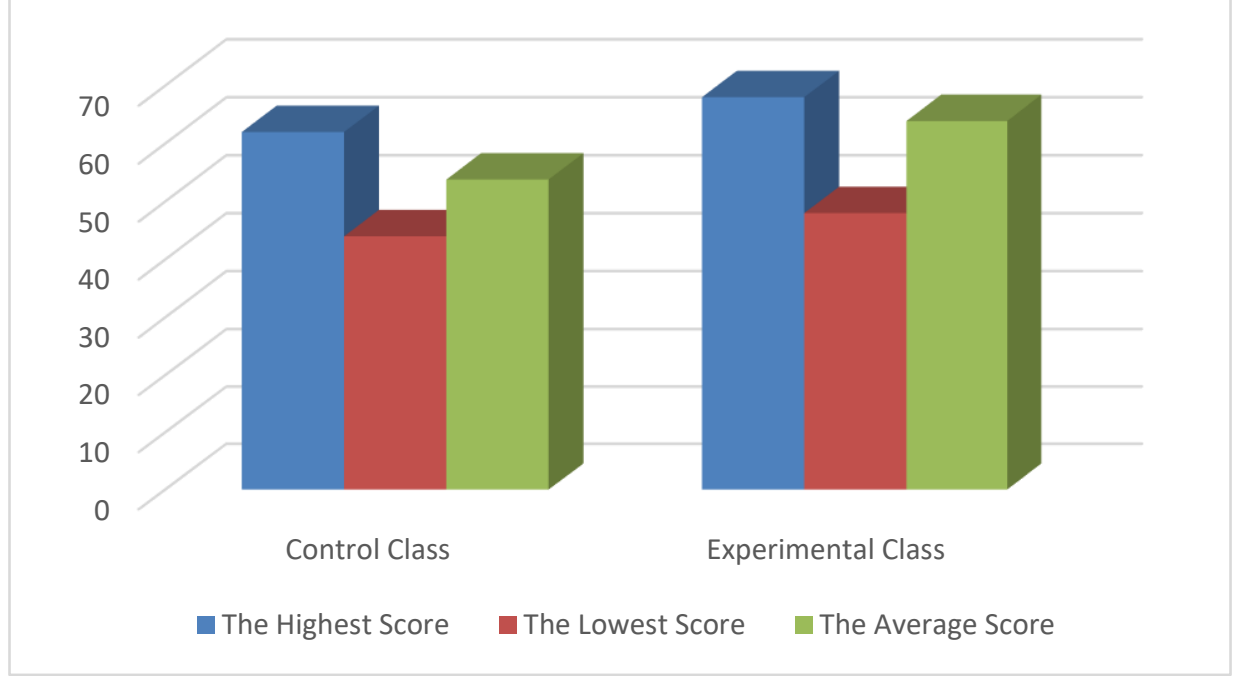

Figure 1. The Data Presentation of Pre-test

\section{Treatment}

The treatments were given for the experimental group only. The treatments of teaching through WebQuest as follows:

\section{a. Meeting 1}

In the early minutes, introduction, giving motivation, and checking the attendance list were done. In this meeting, the students should bring their laptops. The teacher gave some questions related to the computer, after that the teacher explained what they had to do on that day. The material was procedure text with the title How to Operate a Computer (see figure 2).

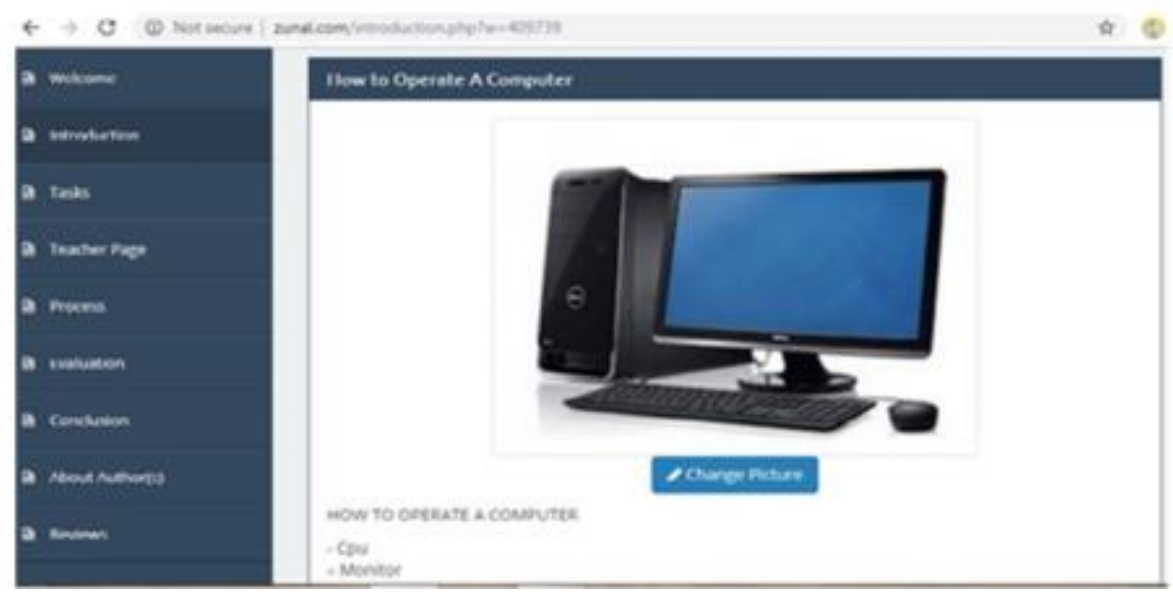

Figure 2. Snapshot of The First Topic

While teaching, the students were explained about procedure text such as generic structure, language features, the purpose of procedure text. They used their laptops to access the link of WebQuest. They were able to see the material and the text on WebQuest. After that, the students and teacher discussed the topic of WebQuest. After that, in each group, they were asked to discuss the answer to the questions. In the last 5 minutes, the teacher gave the link for the next meeting. After that, the teacher gave a conclusion from the lesson and providing a close greeting.

\section{b. Meeting 2}

In the early minutes, introduction, giving motivation, and checking the attendance list were done. In this meeting, the procedure text material was "How to Make Yahoo Account" (see figure 3). The students were still bringing their laptops. They were sitting based on their groups. The teacher explained what they had to do on that day. 


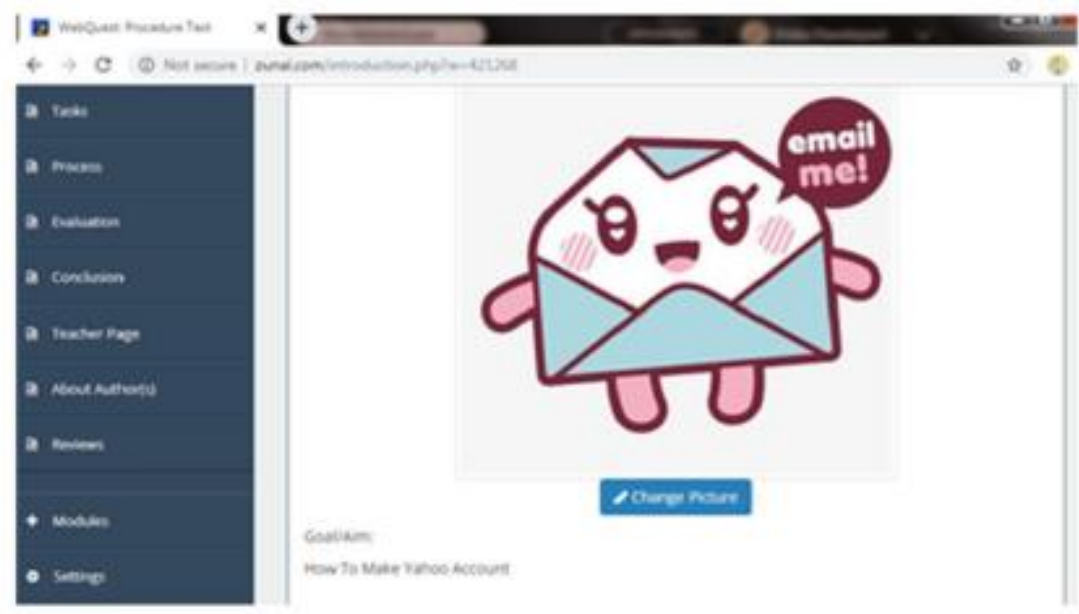

Figure 3. Snapshot of The Second Topic

It was not entirely different from the previous meeting. The teacher was asked to access the link that teacher gave during the last meeting. On WebQuest, some questions should be answered by students in each group. In the final minutes, the teacher gave the conclusion and link for the next meeting.

\section{c. Meeting 3}

In the early minutes, introduction, giving motivation, and checking the attendance list were done. In this meeting, the material of procedure text was "How to Send a Letter to The Email" (see figure 4). The students were still bringing their laptops. They were sitting based on their groups. The teacher explained what they had to do on that day.

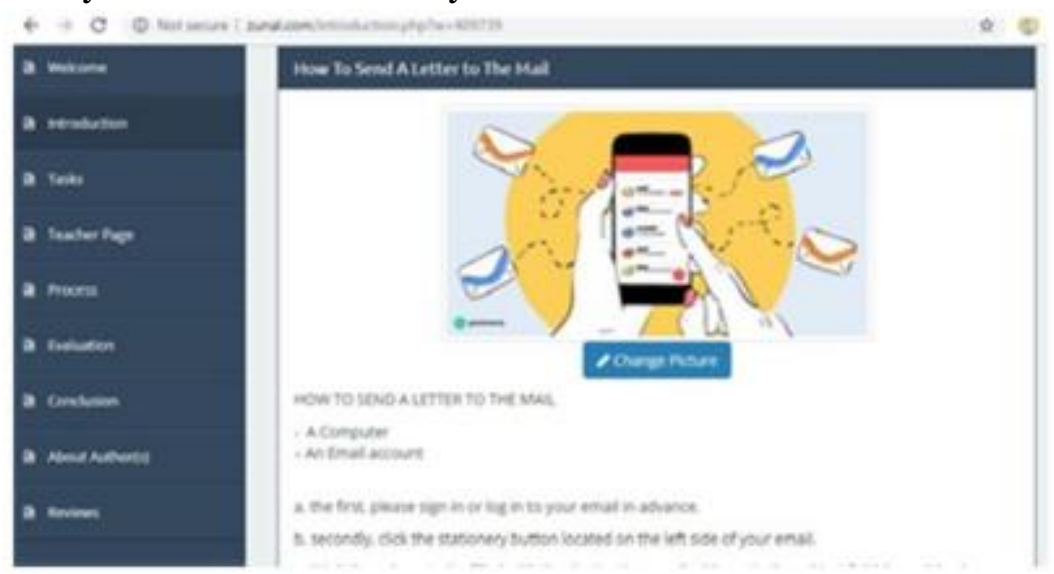

Figure 4. Snapshot of The Third Topic

It was not entirely different from the previous meeting, and the students were asked to access the link that teacher gave in the last meeting. On WebQuest, some questions should be answered by students in each group. In the last minutes, the teacher gave the conclusion and link for the next meeting.

\section{d. Meeting 4}

In the early minutes, introduction, giving motivation, and checking the attendance list were done. In this meeting, the material of procedure text was "How to Use Microsoft Word" (see figure 5). The students were still bringing their laptops. They were sitting based on their groups. The teacher explained what they had to do on that day. 


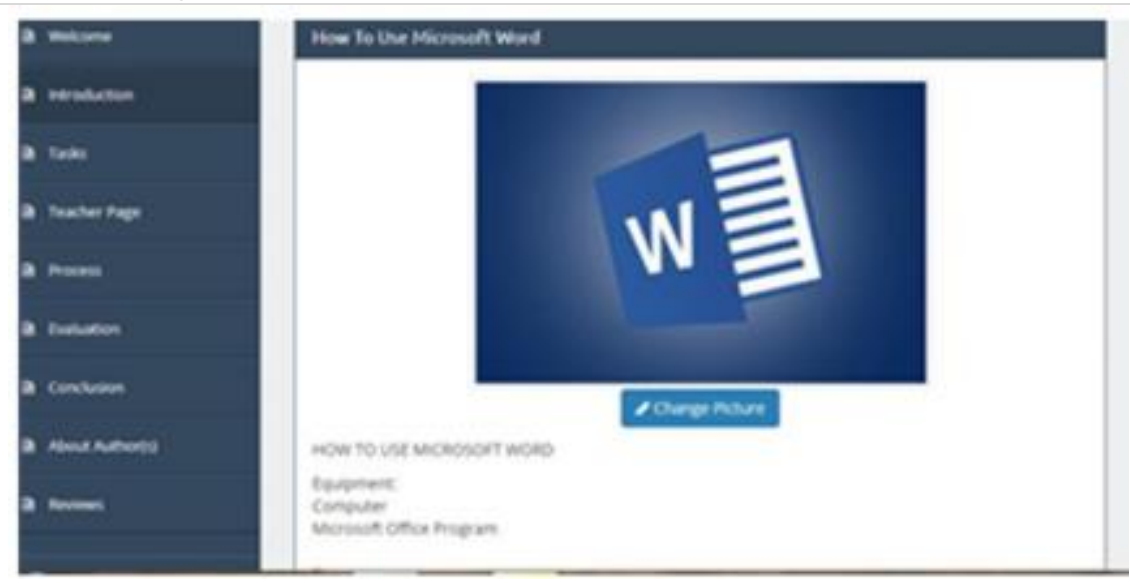

Figure 5. Snapshot of The Fourth Topic

It was not entirely different from the previous meeting. The students were asked to access the link that teacher gave in the last meeting. On WebQuest, some questions should be answered by students in each group. In the last minutes, the teacher gave a conclusion and prepared themselves for the post-test.

\section{Post-Test}

After treatment, this test was administered to know the students' attainment after making procedure text implemented in the classroom process. It was conducted by providing the post-test at the last meeting, writing the text, the purpose of the text, and identifying its generic structure. In the previous meeting, the teacher gave one topic: How to Operate a Computer for the experimental class and How to Charger a Handphone Battery for the control class. Then they were written a procedure text by using their word. After distributing the test to the students, the scores at the pretest and post-test were analyzed to figure out whether or not significant improvement was made by the students after a series of teaching English writing skills used WebQuest.

\section{a. Data Presentation of Post-Test in Control Class}

The students' writing skills, particularly in writing procedure text in the post-test of control class, were as follows; the highest average score was 72, and the lowest average score was 52. Moreover, in the control class, the total score of 20 students was 1.168, and the average score was 58.4 points (See figure 6).

\section{b. Data Presentation of Post-Test in Experimental Class}

The students' writing result particularly in writing procedure text in the post-test of experimental class, as follows; the highest average score was 88, and the lowest average score 64 . Moreover, in experiment class, the total score of 20 students was 1.548 , and the average score was 77.4 (See figure 6). 


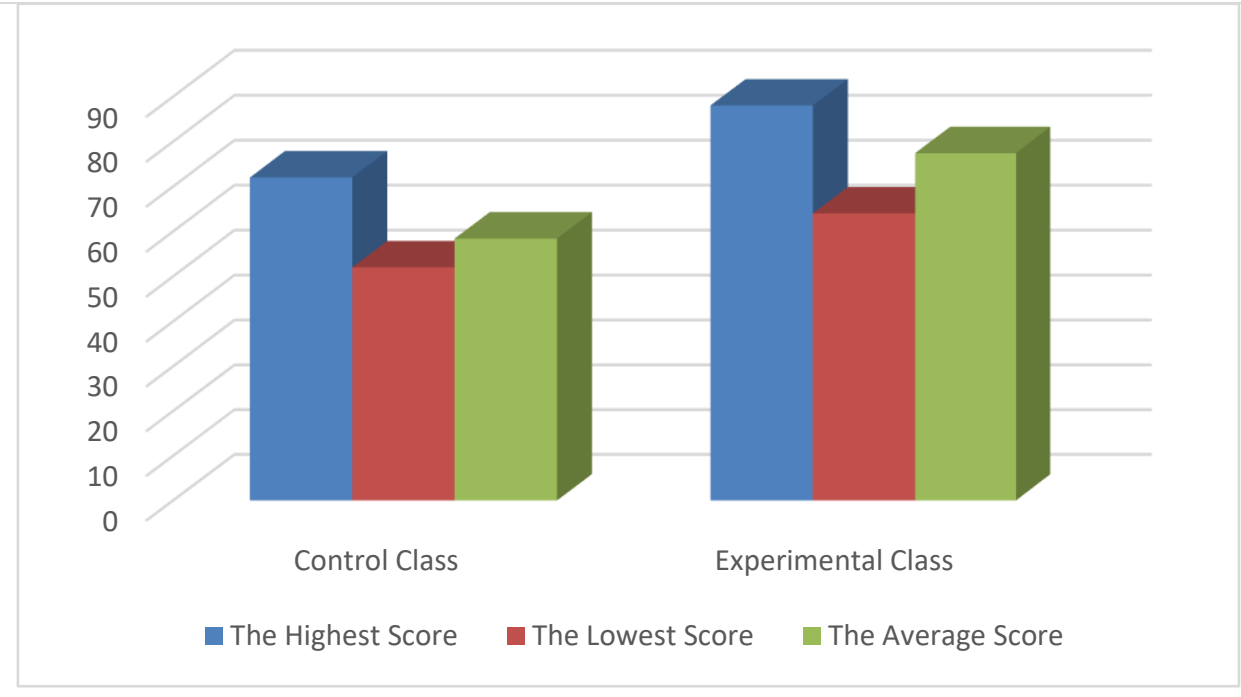

Figure 6. The Data Presentation of Post-test

\section{The Increasing Students' Mean Score of Pre-test and Post-test in Control and Experimental Class}

The researchers obtained the mean score of pre-test and post-test in control and experimental class based on the calculation described. From figure 4.1, it can be seen that the mean score of pretest in the control class was 53, and the mean score of post-test was 58 . While the mean score of the pre-test in the experimental class was 58 and after the students were given the treatment using WebQuest, the post-test mean became 77. It can be summarised that there was a significant effect of WebQuest on students writing at vocational school YPPI Tualang. Furthermore, the increased students' scores between the control and experiment class can be seen in Figure 7.

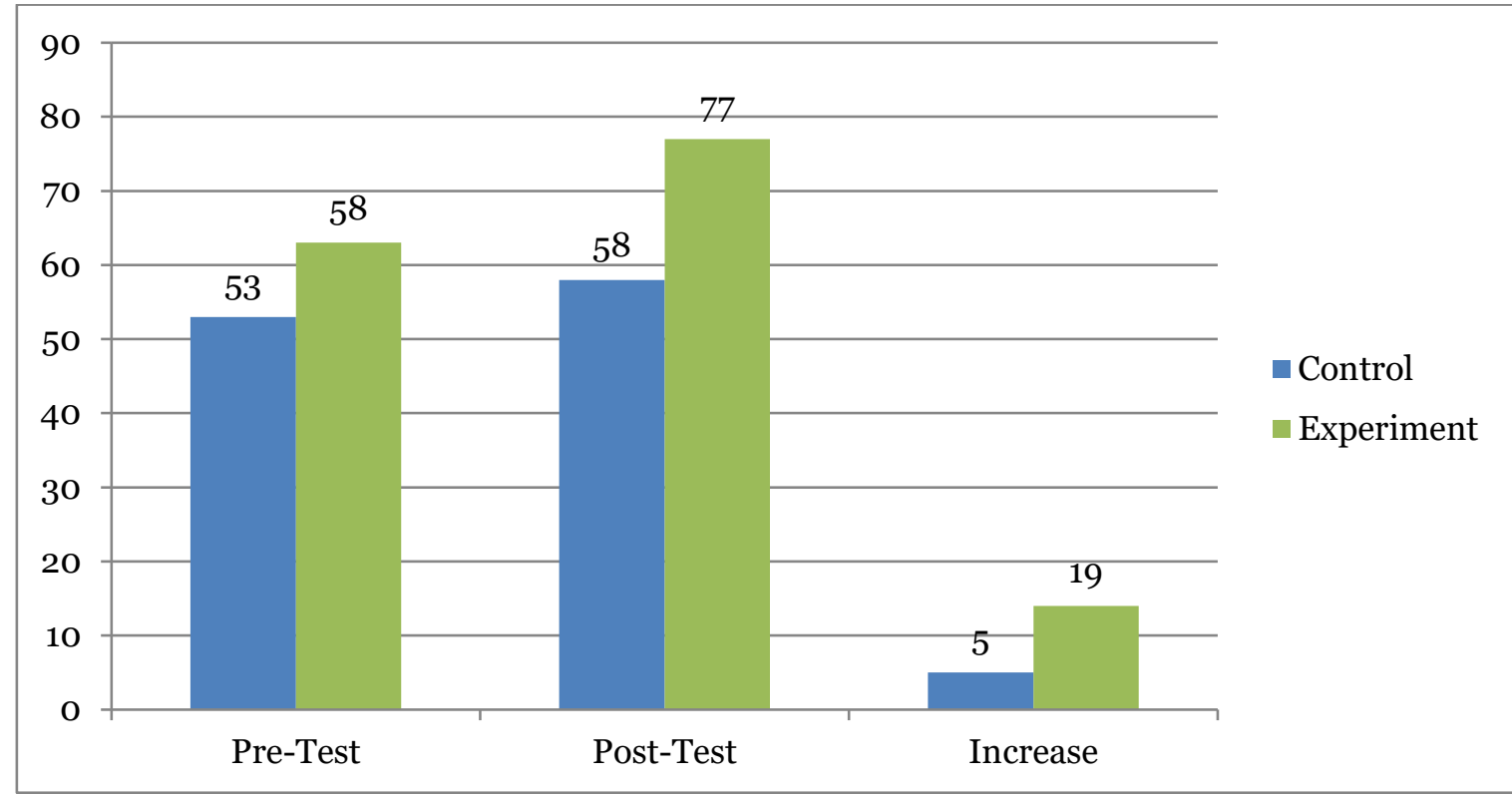

Figure 7. The Difference of Students' Mean Score of Pre-Test and Post-test

In terms of writing aspects achievement, it shows that there was $19 \%$ mastered in developing ideas, 22\% mastered in organizing ideas, 19\% mastered in grammar, and 19\% learned in vocabulary (see figure 8). it can be summarised that students' at SMKS YPPI Perawang were mastered in aspects of writing. It can be seen that after treatment students able to apply the aspects of writing. In brief, every student was a higher score in writing. On the other hand, the next researcher should focus on improving students' writing based on aspects. 


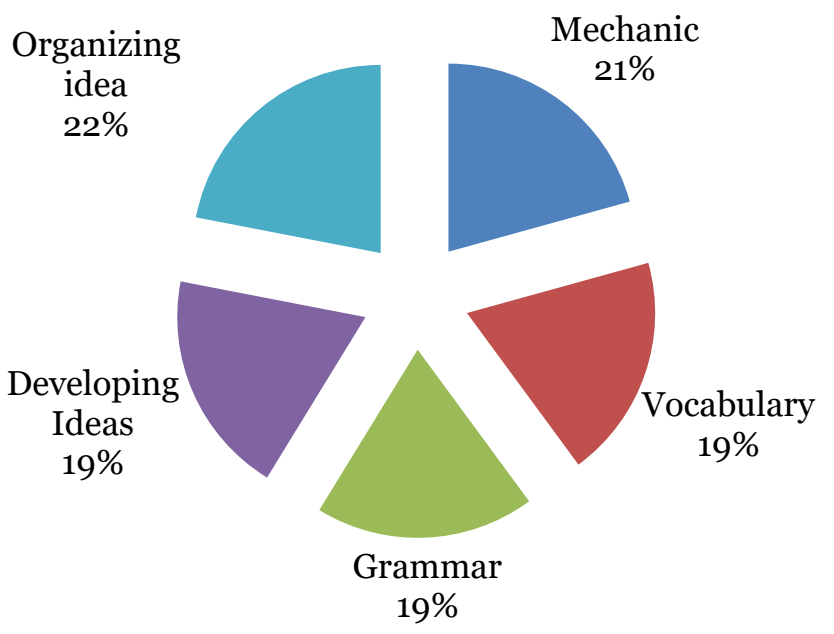

Figure 8. The Aspects of Writing Achieved by the students'

\section{Descriptive Statistic}

Table 1. Descriptive Statistics of Pre-Test and Post-Test

\begin{tabular}{lllllll}
\hline Group & & $\mathrm{N}$ & Minimum & Maximum & Mean & Std. Deviation \\
\hline Control Class & Pre-test & 20 & 44 & 62 & 53.80 & 6.014 \\
& Post-test & 20 & 50 & 72 & 58.40 & 6.125 \\
& Valid N (listwise) & 20 & & & & \\
Experimental Class & pre-test & 20 & 46 & 68 & 58.20 & 5.908 \\
& post-test & 20 & 64 & 88 & 77.40 & 7.598 \\
& Valid N (listwise) & 20 & & & & \\
\end{tabular}

It can be seen from table 1 that there are two classes that compared which was the experimental class and the control class. The experimental class has 20 students, and the mean score of the pretest was 58.20, and the post-test is 77.40, the standard deviation of the pre-test 5.90, and the posttest 7.59. The experimental class has the highest score than the control class. While the control class has 20 students and the mean score of the pre-test was 53.80 , and the post-test was 58.40 , the standard deviation of the pre-test is 6.01, and the post-test is 6.12.

After quantifying the mean score, the researchers analyzed the data using SPPS by using a ttest. It can be seen in table 2 .

Table 2. Output SPPS of Hypothesis Testing

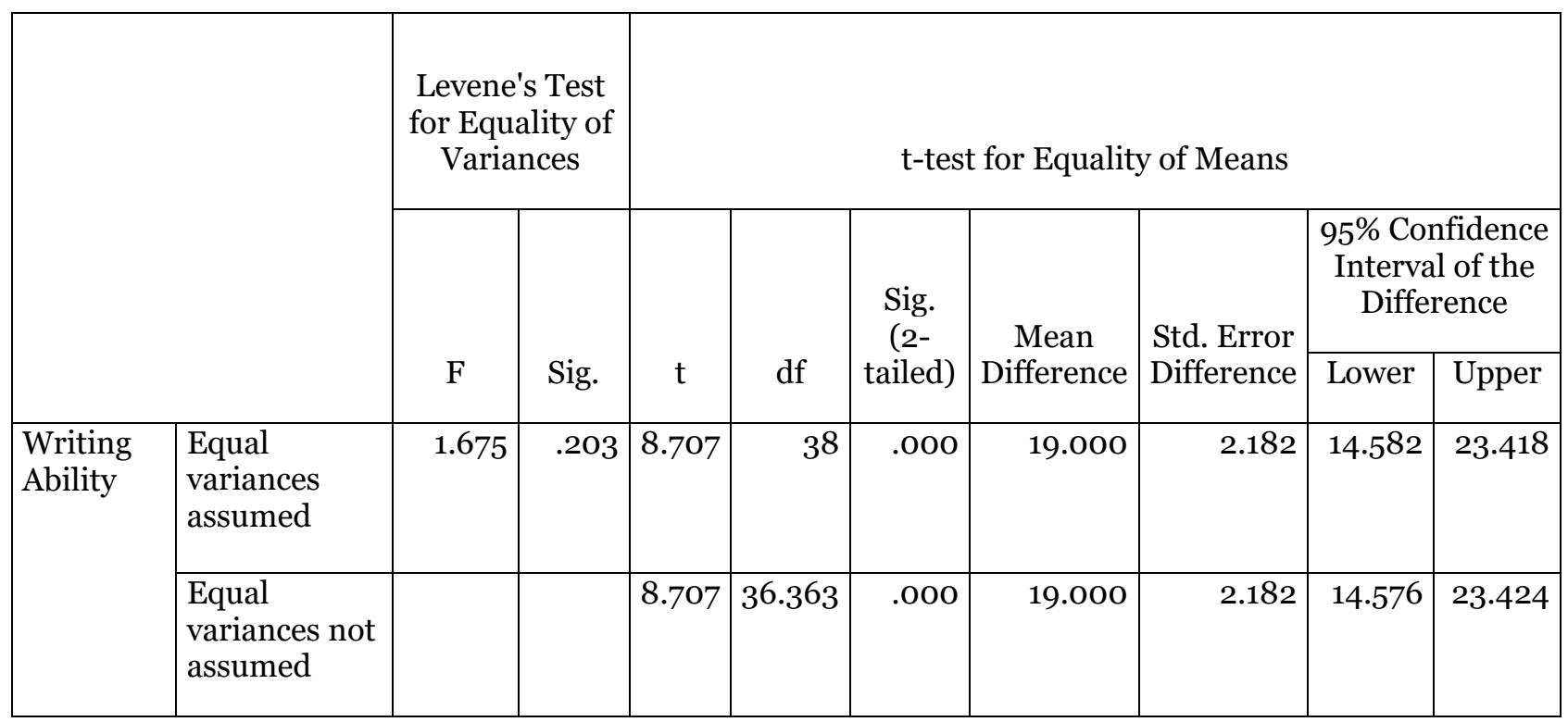


From Table 2, it can be seen that the significant value of $t_{\text {calculate }}$ in Equality of Variances is 0,203 . It can be summarized that Ho is accepted because 0,203 $>0,05$. In brief, it indicates the variance population identic. Further, from the data, $t_{\text {calculate }}$ obtained -8.707 was compared to $t_{\text {table, }}$ $\mathrm{df}=38$ to compare at level $5 \%$ is 2.024. it can be concluded that $t_{\text {table }}$ is higher than $t_{\text {calculate. }}$ In other words, it can be read $8.707>2.024$. Based on the scores, the researchers concluded that Ho is rejected and Ha is accepted. In brief, WebQuest has a significant effect on the second-year students' writing ability at SMKS YPPI Perawang.

It can be implied that WebQuest is effective in improving students' writing. This current result is also confirmed by Alshumaimeri \& Bamanger (2013), Berezova et al. (2018), Chuo (2007), Halat \& Peker (2011), Kocoglu (2010), and Sa'aleek (2018). WebQuest was effective for enhancing in learning English especially writing, and providing a positive learning experience. Besides, the learning model in applying this media is one of the keys to this research's success. In doing the treatments, the researchers conducted a blended learning model adapted and modified from Wahyuni (2018). To run the class, the researchers did asynchronous and synchronous learning. The former was done in the classroom through face-to-face learning, which was the initial activity to prepare the students emotionally and mentally. This activity effectively appeared the students' prior knowledge before having the primary lesson (Wahyuni \& Etfita, 2019). The latter one was synchronous through applying the WebQuest. At the introductory class using WebQuest, the researchers can create a positive atmosphere in learning writing. It can be done due to the various material integrated provide, such as an exciting picture. Moreover, the researchers also offer a structured module.

The researchers also reviewed some past studies to specify the effect of WebQuest on the students' writing ability. In this regard, Ahmed (2016) investigated the effect of using a WebQuest on sixty Egyptian EFL school students' reading and writing skills. A pre/post-test was administered. The results revealed that WebQuest instruction helps EFL learners to improve their reading and writing skills. Almasri et al. (2011) emphasized the WebQuest effect on the writing skills of sixtythree female Saudi EFL learners. Pre-test and post-test were used to gather data. The results of the study indicated a significant improvement in the experimental group's writing performance.

\section{CONCLUSION}

Based on the result of data analysis, research findings, and discussion explained, the researchers concluded the mean score of the pre-test control group was 53.80, and the pre-test experimental group was 58.20. The mean score of the post-test experimental group was 77.40, and the control group was 58.40. It can be summarised that applying WebQuest had any significant effect on students' writing at vocational school YPPI Tualang. In brief, there was a significant effect between the control and experimental group. Students were enhanced and relaxed in the learning writing process when taught through the teaching media WebQuest. Therefore, it implies that WebQuest can keep interaction between students and the teacher and students. It also helps the students to explore and transmit their ideas on writing procedure text. In summary, the use of WebQuest during the research can improve the students' writing procedure text. Therefore, WebQuest needs to be applied continuously in teaching writing procedure text. It is because the use of WebQuest can be effective to help the students practice writing procedure text.

\section{REFERENCES}

Ahmed, M. A. E. A. S. (2016). Web Quest and EFL Critical Reading and Writing. Journal of Cultural and Religious Studies, 4(3), 175-184. https://doi.org/10.17265/2328-2177/2016.03.003

Akhand, M. M. (2015). Project Based Learning (PBL) and WebQuest: New dimension in achieving Learner Autonomy in a Class at Tertiary level. Journal of Pan-Pacific Association of Apllied Linguistics, 19(2), 55-74. http://ci.nii.ac.jp/naid/110007380519/

Almasri, M., Alfadda, H., \& Alshumaimeri, Y. (2011). A preliminary study of the effect of WebQuests on the writing performance of Saudi female EFL elementary school students. The JALT CALL 
Alshumaimeri, Y. A., \& Bamanger, E. M. (2013). The Effects of WebQuest Writing Instruction on the Writing Performance of Saudi Male EFL Learners. Procedia - Social and Behavioral Sciences, 83, 960-968. https://doi.org/10.1016/j.sbspro.2013.06.179

Barros, A., \& Carvalho, A. (2007). From WebQuests to a ReadingQuest: learners' reactions in an EFL extensive reading class. Digital Education Review, 15(15), 37-51.

Berezova, L. V, Mudra, S. V, \& Yakushko, K. H. (2018). The Effect of WebQuests on The Writing and Reading Performance of University Students. Information Technologies and Learning Tools, 64(2), 110-118.

Chuo, T.-W. (2007). The Effects of the WebQuest Writing Instruction Program on EFL Learners' Writing Performance, Writing Apprehension, and Perception. Teaching Englsh as a Second or Foreign Language, 11(3), 1-27.

Creswell, J. W. (2013). Research Design: Qualitative, Quantitative, and Mixed Methods Approaches. In Research design Qualitative quantitative and mixed methods approaches. https://doi.org/10.1007/s13398-014-0173-7.2

Dodge, B. (1997). Some thoughts about WebQuests. http://webquest.sdsu.edu/about_webquests.html

Ghavifekr, S., \& Rosdy, W. A. W. (2015). Teaching and Learning with Technology: Effectiveness of ICT Integration in Schools. International Journal of Research in Education and Science (IJRES), 1(2), 175-101. https://doi.org/10.21890/ijres.23596

Hadriana. (2017). WebQuest Application to Improve English Writing Skill. International Journal of Software Engineering Anf Its Applications, 11(4), 61-68.

Halat, E., \& Peker, M. (2011). The impacts of mathematical representations developed through webquest and spreadsheet activities on the motivation of pre-service elementary school teachers. Turkish Online Journal of Educational Technology, 1O(2), 259-267.

Irzawati, I., \& Asiah, N. (2013). Using Webquest in Learning Grammar: Students' Perceptions in Higher Education. Advances in Language and Literary Studies, 4(1), 13-19. https://doi.org/10.7575/aiac.alls.v.4n.1p.13

Kocoglu, Z. (2010). WebQuests in EFL reading/writing classroom. Procedia - Social and Behavioral Sciences, 2(2), 3524-3527. https://doi.org/10.1016/j.sbspro.2010.03.545

Lipscomb, G. (2003). "I Guess It Was Pretty Fun": Using WebQuests in the Middle School Classroom. The Clearing House: A Journal of Educational Strategies, Issues and Ideas, 76(3), 152-155. https://doi.org/10.1080/o0098650309601993

Pinantoan, A. (2013). Webquests - An Introductory Guide and Resources. http://www.opencolleges.edu.au/informed/teacher-resources/webquests/

Raja, F. U., \& Khan, N. (2018). Comparing Traditional Teaching Method and Experiential Teaching Method using Experimental Research. Journal of Education and Educational Development, 5(2), 276. https://doi.org/10.22555/joeed.v5i2.1816

Sa'aleek, R. A. (2018). The Effect of Using WebQuests on Improving Jordanian Eight Graders' Grammar Learning. International Journal of Education, Learning and Development, 6(11), 115 .

Şahin, S. M. S., \& Baturay, M. H. (2016). The effect of 5 E-learning model supported with WebQuest media on students' achievement and satisfaction. E-Learning and Digital Media, 13(3-4), 158175. https://doi.org/10.1177/2042753016672903

Strickland, J., \& Nazzal, A. (2005). Using webquests to teach content: Comparing instructional strategies. Contemporary Issues in Technology and Teacher Education, 5(2), 138-148. http://www.editlib.org/p/6042/

Sung, Y. T., Chang, K. E., \& Liu, T. C. (2016). The effects of integrating mobile devices with teaching and learning on students' learning performance: A meta-analysis and research synthesis. Computers and Education, 94, 252-275. https://doi.org/10.1016/j.compedu.2015.11.008

Wahyuni, S. (2017). Students' Ability in Writing Hortatory Exposition of Eleventh Grade Students at SMAN 14 Pekanbaru. Journal of English for Academic, 4(2), 87-93. http://journal.uir.ac.id/index.php/jshmic/article/view/537

Wahyuni, S. (2018). The Effect of Blended Learning Model towards Students' Writing Ability. Journal of English for Academic, 5(2), 97-111. https://doi.org/10.25299/jshmic.2018.vol5(2).1801

Wahyuni, S. (2015). Improving Students' Writing Ability Through Writing Tasks of the Second Year Students at SMAN 2 SiakHulu Kampar District. International Seminar on English Language 
Teaching (ISELT) 3, 438-441.

Wahyuni, S., \& Etfita, F. (2019). Language Attitude towards Blended Learning Model for Writing $\begin{array}{lll}\text { Subject. } \quad A L-I S H L A H: & \text { Jurnal }\end{array}$ https://doi.org/10.35445/alishlah.v11i2.141

Wu, C.-P. (2016). Bridging the Web: WebQuests in Writing Classrooms. Int. J. Online Pedagog. Course Des., 6(3), 26-38. https://doi.org/10.4018/IJOPCD.2016070103

Zheng, R., Stucky, B., McAlack, M., Menchana, M., \& Stoddart, S. (2005). Webquest learning as perceived by higher-education learners. TechTrends, 49(4), 41-49. https://doi.org/10.1007/bfo2824110 